\title{
THE ADOPTION OF IFRS 10 AND ITS IMPACT ON THE SCOPE OF CONSOLIDATION
}

\author{
[Přijetí IFRS 10 a jeho dopady na sestavení konsolidačního celku] \\ Tereza Gluzová ${ }^{1}$ \\ ${ }^{1}$ University of Economics in Prague, Faculty of Finance and Accounting, Department of Financial Accounting \\ and Auditingu, Winston Churchill Square 4,130 67Prague 3, Czech Republic \\ Email:xglut00@vse.cz.
}

\begin{abstract}
Consolidated financial statements present aggregated information for a group formed by the parent company and its subsidiaries. The existence of control is the most important condition to determine the relationship between companies within the group. This article focuses on the adoption of a novelised control concept introduced by IFRS 10. Companies quoted on Prague and Warsaw stock exchanges were chosen to illustrate the impact of IFRS 10. The article provides an analysis of consolidated financial statements in a year of the adoption of IFRS 10 and a year immediately preceding. Summarized findings reveal whether IFRS 10 had a material impact on consolidated financial statements.
\end{abstract}

Keywords: consolidated financial statements, control concept, financial reporting, IFRS.

JEL classification: M41

Doručeno redakci: 3.12.2015; Recenzováno: 10.12.2015; 21.12.2015; Schváleno k publikování: 23.3.2016

\section{Introduction}

Consolidated financial statements aim to present financial information for the group of companies as if they were a single economic unit. The group is formed by the parent company and subsidiary companies, which the parent controls. In the Czech Republic, as well as in all member countries of the European Union (EU), consolidated financial statements of companies, whose equity or debt securities are listed on a regulated market, must be prepared in conformity with International Financial Reporting Standards (IFRS). In addition, non-listed companies in the Czech Republic that obligatorily or voluntarily prepare consolidated financial statements have been given an option to apply either Czech accounting standards or IFRS.

Until the end of 2013, an international standard IAS 27 Consolidated and Separate Financial Statements was in force to prepare consolidated financial statements. For accounting periods beginning 1 January 2014 and later, rules for consolidated financial statements were relocated to IFRS 10 Consolidated Financial Statements. IFRS 10 has not changed the principles of consolidation. The main aim is still to present asset, liabilities, equity, income, expenses and cash flows of the parent and subsidiary companies as if they were one (fictional) economic entity and intragroup transactions did not exist. The most substantial impact of IFRS 10 is the newly introduced control concept used to decide which companies will be included in the consolidated statements. The correct identification of control and subsequently compilation of the group has a vital impact on the value relevance of consolidated financial statements. When the parent omits a subsidiary company or conversely consolidates an entity it does not control, output of the consolidated statements cannot give a true and fair view.

This article analyzes the impact of IFRS 10 on consolidated financial statements of selected companies and is organised as follows. The first chapter is devoted to the development of the 
control concept and explains the reasons why the new consolidation standard was adopted. The second part of the article reviews the relevant literature. The third chapter describes the methodology of the study. Empirical results are presented in the fourth chapter. The final part of the article discusses the outputs of the analysis.

The main aim of the study is to investigate whether companies' reporting practices and accounting policies changed in response to IFRS 10. To answer the research question, I have compared financial statements of each company in the year of the adoption of IFRS 10 and the year immediately preceding. The research sample consists of 43 companies quoted on Prague Stock Exchange and Warsaw Stock Exchange. Based on the analysis, I assess materiality of changes following the adoption of the revised control concept. In addition, I examine whether accounting policies for the definition of control were updated. The results of the empirical study are confronted with the preliminary effect analysis of IFRS 10 and thus reveal differences between an expected and an actual impact. Therefore the findings could be of a particular interest to the authors of the preliminary effect analyses as well as other researchers. The outcomes of the study may serve as a comparative basis for the studies realized on different markets.

\section{Definition of control}

Not long ago, control was defined by IAS 27 as the power to govern the financial and operating policies of an entity so as to obtain benefits from its activities. Control was deemed to exist when the parent company had more than half of the voting rights in another entity. The standard considered also situations, where control existed without the majority of voting rights and mentioned contractual agreements or ability to appoint the majority of the members of the governing body. Nevertheless, voting rights were perceived to be primarily, and often the only, indicator of the relationship of control between companies.

At the same time, the interpretation of SIC-12 Special Purpose Entities was applied to decide whether a special purpose entity (SPE) should be included in consolidated financial statements. According to the interpretation, the company consolidated SPE based on the exposure to risks and rewards from its activities. Principles of control in IAS 27 and SIC-12 varied and caused numerous inconsistencies when deciding about control over an entity. International Accounting Standards Board (IASB, the standard-setting body for IFRS) therefore decided to work on a project to unify the control principles and reduce the area for the possible dual approach.

In 2011, after almost ten years of work, IASB issued a set of new or amended standards on consolidation and related issues. The date of the obligatory application for companies in the European Union was set for accounting periods beginning 1 January 2014 and later. This was a year later than the official IASB application date, as all standards have to undergo the endorsement process and become part of the European legislation in order to be applicable in the European Union.

From this set of standards, IFRS 10 Consolidated financial statements affected the view on the scope of consolidation. IFRS 10 amended the definition of control which is currently based on several conditions. The investor controls and an investee when three conditions are met:

- power over the investee;

- exposure to variable returns from the investee; and

- ability to use power to affect the returns. 
The new definition of control is more general than those in IAS 27 and SIC-12. Although voting rights are still mentioned as an indicator of power over the investee, the standard states that majority of voting rights may not be sufficient to have power (and thus control). More importantly, standard setters included situations when power exists despite the investor possessing less that $50 \%$ of voting rights. Mainly in case of structured entities ${ }^{1}$, power may arise from other than voting rights. Consequently, chapters on power and control when voting rights do not have a significant impact on the investee's returns have been included.

Effects of the adoption of new standards and amendments shall be presented in the notes to the financial statements, which is the requirement of IAS 8 Accounting Policies, Changes in Accounting Estimates and Errors. The newly adopted or amended accounting policy shall be primarily applied retrospectively and statements need to be amended as if the accounting policy has always been in force. In general, the retrospective application leads to the adjustment to both opening balances and comparative numbers presented for the prior period(s). At the same time, IFRS 10 contains a transition guidance to assist companies with the transition from IAS 27 and SIC-12 respectively.

The adoption of IFRS 10 may generate following outcomes:

- no impact on the scope of consolidation

Unless the adoption of IFRS 10 has an impact on the scope of consolidation, it is not necessary to make an adjustment to the financial statements. As far as the retrospective application is concerned, the standard is less strict. The parent does not need to consolidate its former interest in a company which would comply with the definition of the subsidiary under IFRS 10 but over which control was lost before the date of the initial application of IFRS 10.

- the consolidation of a new subsidiary company

The adoption of the new control concept may lead to the conclusion that a new subsidiary company shall be consolidated. The investor restates its financial statements as if the subsidiary was consolidated from the date the control was obtained according to IFRS 10.

- the deconsolidation of a former subsidiary company

The investor concludes that interest in a consolidated company does not conform to the definition of control under IFRS 10. Financial statements must be adjusted as if the company was never consolidated.

\section{Review of the relevant literature}

An important role of consolidated financial statements in comparison with separate (parentonly) financial statements was proved in studies by Müller (2011), Abad et al. (2000) or Niskanen, Kinnunen and Kasanen (1998). Accepting this presumption, further analysis of the quality of consolidated statements after the IFRS adoption was undertaken by Müller (2011). The author investigated consolidated reports of companies quoted on London, Paris and Frankfurt stock exchanges and confirmed the hypothesis about an increased value relevance when IFRS were applied.

\footnotetext{
${ }^{1}$ IFRS 10 uses term „structured entity“ instead of „special purpose entity“. Although not equal, both terms have similar meaning. Structured entity is defined as an entity designed so that voting or similar rights are not the dominant factor in deciding who controls the entity.
} 
According to Müller, Cardos and Ienciu (2010), the control concept holds a major role in determining the scope of consolidation in both international, American and European accounting standards. Their study summarizes the development of approaches to the concept of control. A detailed overview of the historical and current perception of the scope of consolidation and the differences between ownership and control is described by Nobes (2014). In recent years many authors have analyzed new consolidation requirements brought by IFRS 10, i.e. Gornik-Tomaszewski and Larson (2014); Zelenková (2014) or Büdy-Rósza (2012). Van Noordwyk and Wise (2014) expect the most significant changes in the banking and insurance industry as a result of the IFRS 10 adoption. Such a conclusion was supported also by van der Merwe (2013).

Prior to the issuance of IFRS 10, IASB had cooperated with both companies preparing consolidated statements and users of financial statements in order to anticipate its impact. The effect analysis (IASB, 2013) shows that in a vast majority of cases, conclusions about the consolidation of a company are identical under both IAS 27 (SIC-12 respectively) and IFRS 10. Another preliminary study on impacts of IFRS 10 on EU companies was carried out by EFRAG $^{2}$ (2012). Participants to the study appreciated the uniform approach to control, clearer definitions and provided guidance. At the same time, companies mainly from the banking and insurance industry expressed possible changes in control conclusion regarding structured entities. 17 companies from the study sample had interest in structured entities. Six of those admit consolidating structured entities under IFRS 10 which were not controlled under IAS 27/SIC-12. On the other hand, seven companies encountered the fact they would no longer consolidate some of structured entities once IFRS 10 had been adopted. It could therefore seem that banks and insurance companies will be most affected by changes in the control concept.

There has been no study however to assess the impact on consolidated financial statements of companies in years after the IFRS 10 adoption. This may be due to the recent adoption of IFRS 10 by European companies. Year 2014 was the first accounting period in which IFRS 10 and related consolidation standards were applied by the majority of the companies in the EU. Therefore, appropriate information and data to undergo a thorough analysis were not available until 2015. With the issuance of consolidated financial statements for year 2014 where the new control concept was applied, a full impact of IFRS 10 is finally to be evaluated. That is subject to further analysis in this article.

\section{Methodology}

This work evaluates the impact of IFRS 10 on consolidated financial statements of companies listed on Prague and Warsaw stock exchanges. The economics of the Czech Republic and Poland display many similarities and therefore stock exchanges of these two countries were chosen to be the subject of the analysis. Slovakia was primarily included in the analysis, however due to a low liquidity and a limited importance of SAX (index of Bratislava Stock Exchange), it was subsequently withdrawn.

Companies included in the research sample were selected in a several steps. At first, companies included in the calculation of WIG30 (for Warsaw Stock Exchange) and PX (for Prague Stock Exchange) indices as at 15 September 2015 were selected. The presumption was that companies from those indices formed the major companies quoted on the stock exchanges. Subsequently, companies presenting financial statements in accordance with the

\footnotetext{
${ }^{2}$ European Financial and Reporting Advisory Group (EFRAG) is an organisation cooperating with European Commission on endorsement process of IFRS into European law
} 
reporting framework other than IFRS were excluded. As the analysis deals with financial statements for two consequent years, companies whose financial statements for one of the years were not available were excluded in the next step.

From a total of 43 companies, three were eliminated because of the reasons specified above. The final sample comprises 40 companies and can be found in Appendix A. Financial statements of the companies were further analysed, with an emphasis on:

- the year of the initial application of IFRS 10;

- the definition of control after the adoption of IFRS 10; and

- the impact of the IFRS 10 adoption on the scope of consolidation.

\section{Results and discussion}

The majority of the companies adopted IFRS 10 consistently with the EU effective date that is 1 January 2014. Figure 1 reveals, that there were however 7 companies opting for an early application already in 2013.

Figure 1: The adoption of IFRS 10 by years

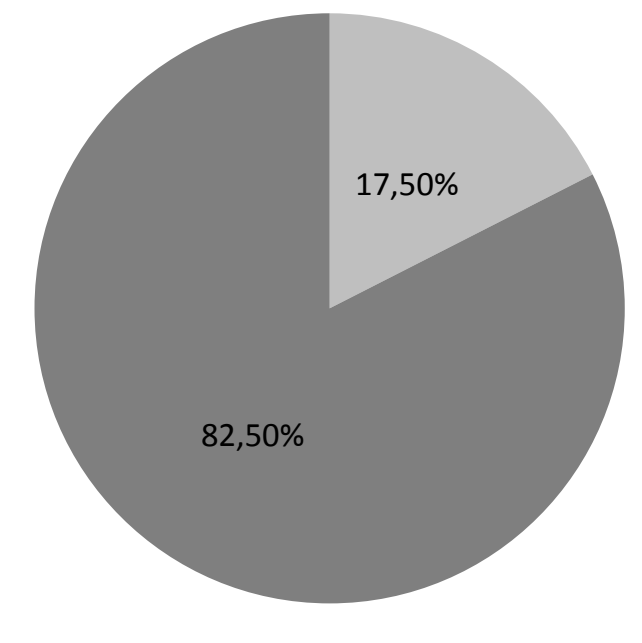

Early adopted in $2013 \quad$ Adopted in 2014

Source: compiled by the author based on financial statements of selected companies

In the notes to the financial statements, companies shall present information about the basis of the preparation of the financial statements and significant accounting policies relevant to understand the financial statements. As far as consolidated statements are concerned, information about the basis of consolidation and policies used to determine control over an entity are undoubtedly of high relevance. Although not explicitly required by the standards, the vast majority of the companies included the definition of control in the notes to the financial statements, as presented in Figure 2. The determination of control of ten companies remains focused on obtaining benefits though power over financial and operating policies. This implies that the accounting policy has not been updated since they use the definition based on IAS 27 rather than IFRS $10.70 \%$ of the companies adjusted the definition to comply with the new control concept, highlighting power, variable returns and linkage between those. 
Figure 2: The definition of control in financial statements

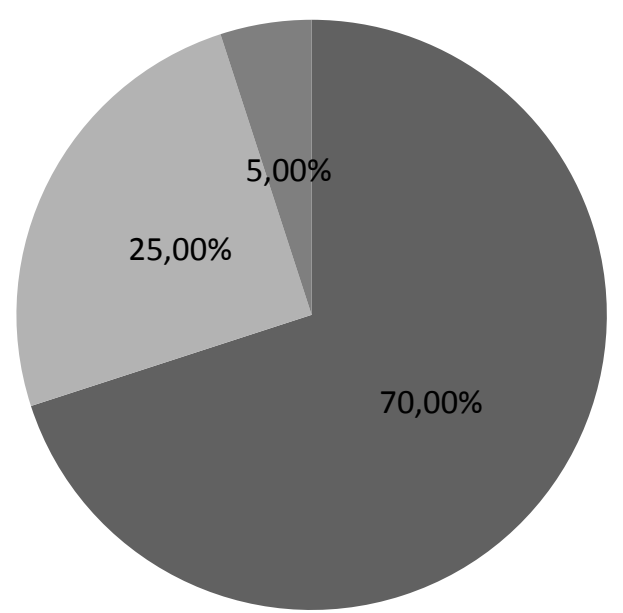

- In accordance with IFRS $10 \quad$ In accordance with IAS $27 \quad$ No definition

Source: compiled by the author based on financial statements of selected companies

To illustrate the impact of IFRS 10, financial statements of the companies following the year of the initial adoption were analysed. The analysis yielded the results summarised in Figure 3:

Figure 3: The impact of IFRS 10 on consolidated financial statements

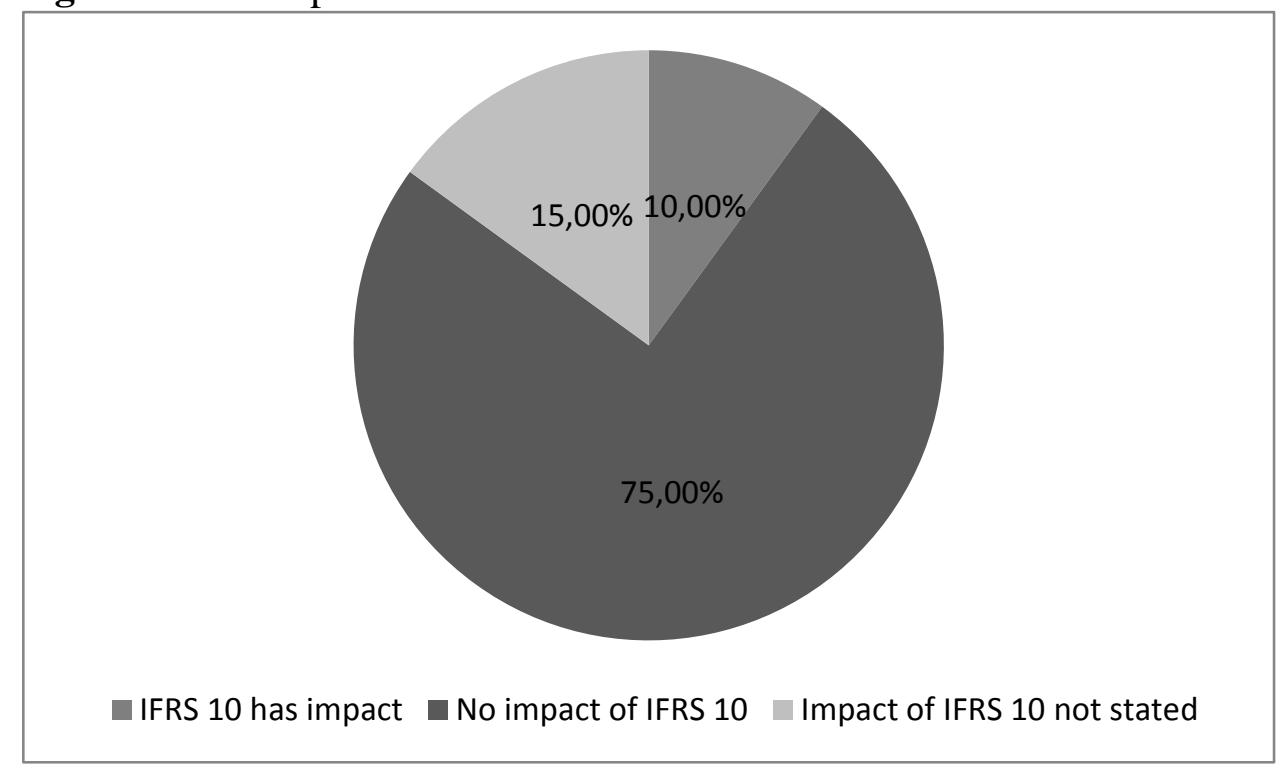

Source: compiled by the author based on financial statements of selected companies

Three quarter of the companies stated the adoption did not impact their scope of consolidation. Six companies did not describe results of the IFRS 10 adoption. It could be presumed there was also no impact since if it were otherwise, it would have to be described in the notes to the financial statements.

Four companies (i.e. 10\%) experienced the adoption of IFRS 10 to influence their financial statements. The assessment of control under the new control concept led to the consolidation of 26 new subsidiaries in total. On the other hand, no former subsidiary company was deconsolidated. Table 1 provides the information about companies affected by IFRS 10: 
Table 1: Companies affected by IFRS 10

\begin{tabular}{|l|l|r|l|}
\hline \multicolumn{1}{|c|}{ Company } & \multicolumn{1}{|c|}{ Industry } & No. of subsidiaries & \multicolumn{1}{c|}{ Impact of IFRS 10 } \\
\hline Asseco Poland S.A. & IT & 210 & $\begin{array}{l}\text { Retrospective consolidation of 3 new } \\
\text { subsidiaries }\end{array}$ \\
\hline Erste Group Bank AG & Banking & 328 & $\begin{array}{l}\text { Retrospective consolidation of } 18 \\
\text { investment funds }\end{array}$ \\
\hline $\begin{array}{l}\text { Powszechny Zakład } \\
\text { Ubezpieczeń S.A. }\end{array}$ & Insurance & 131 & $\begin{array}{l}\text { Retrospective consolidation of } 4 \\
\text { subsidiaries }\end{array}$ \\
\hline $\begin{array}{l}\text { VIENNA INSURANCE } \\
\text { GROUP }\end{array}$ & Insurance & subsidiary \\
\hline
\end{tabular}

Source: compiled by the author based on financial statements of selected companies

All companies in question presented the restated financial data to illustrate the effect of IFRS 10. The restatement of financial statements (undertaken at the date immediately preceding the day of the initial application of IFRS 10, i.e. at 31 December 2013) resulted in an increase of total assets for three companies, whereas Vienna Insurance Group detected a decrease. The largest impact had been recorded by Asseco Poland S.A., whose total assets increased by $3.35 \%$ as a result of the retrospective consolidation of three newly detected subsidiaries. The impacts are summarised in the Table 2 (amounts in CZK thousand, recalculated using exchange rates of the Czech National Bank as at 31 December 2013).

Table 2: Quantitative effects of IFRS 10 adoption

\begin{tabular}{|l|r|r|r|r|}
\hline \multicolumn{1}{|c|}{ Company } & \multicolumn{2}{c|}{ Impact on total assets } & \multicolumn{1}{c|}{$\begin{array}{c}\text { Total assets after } \\
\text { restatement }\end{array}$} & Change in \% \\
\hline Asseco Poland S.A. & increase by & 2204081 & 65859643 & $3,35 \%$ \\
\hline Erste Group Bank AG & increase by & 6773975 & 5870897175 & $0,12 \%$ \\
\hline $\begin{array}{l}\text { Powszechny Zakład } \\
\text { Ubezpieczeń S. A. }\end{array}$ & increase by & 2805502 & 414584568 & $-0,16 \%$ \\
\hline $\begin{array}{l}\text { VIENNA INSURANCE } \\
\text { GROUP }\end{array}$ & decrease by & 1798230 & 1149418006 & $\mathbf{0 , 1 3 \%}$ \\
\hline Total & increase by & $\mathbf{9 9 8 5 3 2 9}$ & $\mathbf{7 5 0 0 7 5 9 3 9 2}$ & \\
\hline
\end{tabular}

Source: compiled by the author based on financial statements of selected companies

\section{Conclusion}

With the introduction of the revised control concept by IFRS 10, companies were required to review, whether they actually consolidate each investee they control and vice versa whether each consolidated subsidiary is under control. The findings of the article reveal that only $10 \%$ of the companies identified changes to their scope of consolidation. Following the IFRS 10 adoption, total assets after restatement arose by $0.13 \%$. A total of 26 formerly nonconsolidated investees met the revised definition of control. As a result, the IFRS 10 adoption led to the consolidation of these 26 newly identified subsidiaries. Out of the four affected companies, there were two insurance companies, one bank and one company from the IT industry. This industry structure is in line with the effect analysis by EFRAG (2012), where the banks and insurers were assumed to experience the most significant effect.

The amended concept of control introduced by IFRS 10 was not expected to cause vast changes to the conclusion whether control over a company exists. Such were the opinions presented by IASB (2013). In their analysis, IASB explains: “...IFRS 10 does not introduce new concepts. Instead, it builds on the control guidance that existed in IAS 27 and SIC-12 but adds additional context, explanation and application guidance..." With regards to the 
companies on Prague Stock Exchange, similar results (i.e. limited adjustments to the scopes of consolidation) were predicted by Vašek and Gluzová (2014).

Results of the analysis confirmed those expectations. There was a slight increase in the number of the consolidated companies, nevertheless the change of $0.13 \%$ with respect to the total assets may be evaluated as insignificant. Moreover, the study revealed an inconsistency in the accounting policies of some companies. All companies proclaimed their judgements applied when assessing control over investees were revised. However $25 \%$ of the companies from the research sample remain to define control in accordance with the former IAS 27. Such mixed outcomes cast a doubt on the credibility of the financial statements. The inconsistent definition of control may be caused a lack of attention. On the other hand, it is possible that the revised control concept has not been properly applied.

The article focuses on the impact of the IFRS 10 adoption with respect to the materiality of changes to the scope of consolidation. The limitation of the outputs therefore is that it cannot evaluate the usefulness of the revised control concept to the primary users of the financial statements. The second potential limitation lies in the research sample, which consists only of the companies quoted on Prague and Warsaw stock exchanges. There are possibilities of a further research based on the outputs of this study. First of all, future studies could evaluate the relation between the value relevance of the consolidated financial statements and the IFRS 10 adoption. More detailed results may be obtained also with the extension of the research sample.

Regardless of the limitations, the study contributes to the literature by providing the first-ever analysis of the revised control concept after IFRS 10 was adopted. The introduction of IFRS 10 was accompanied by a number of preliminary effect studies. These may be compared with the findings this analysis. Thus, the study reveals the differences between an anticipated and actual impact. Standard setters could benefit from the analysis when post-implementation review of IFRS 10 is held. The findings of the study are also of interest to the future researchers who focus on the consolidated financial statements.

\section{Acknowledgement}

This article is processed as an output of a research project registered by the Internal Grant Agency of University of Economics F1/47/2015 „Relevance of Accounting Information on Consolidated Basis in Business and Public Sector" [in Czech: Relevance účetních informací na konsolidovaném základu v podnikatelském i veřejném sektoru].

\section{References}

[1] ABAD, C. et al., 2000. An Evaluation of the Value Relevance of Consolidated versus Unconsolidated Accounting Information: Evidence from Quoted Spanish Firms. Journal of International Financial Management and Accounting, 11(3), 156-177. ISSN 09541314.

[2] BÜDY-RÓSZA, I., 2012. New Trends in Consolidation - Challenging the Changes of new IFRS rules. Periodica Polytechnica. Social and Management Sciences, 20(1), 11-22. ISSN 1416-3837.

[3] EFRAG, 2012. Feedback report on field-tests on IFRS 10, IFRS 11 and IFRS 12 [online]. [vid. 1th November 2015]. Available from: www.efrag.org/ files/EFRAG\%20public\%20letters/Consolidation/Feedback_report_on_field_tests_on_IF RS_10_IFRS_11_and_IFRS_12.pdf 
[4] GORNIK-TOMASZEWSKI, S. and R. K. LARSON, 2014. New Consolidation Requirements under IFRS. Review of Business, 35(1), 47-58. ISSN 0034-6454.

[5] IASB, 2013. Effect analysis. IFRS 10 Consolidated Financial Statements and IFRS 12 Disclosure of Interests in Other Entities [online]. [vid. 1th November 2015]. Available from: www.ifrs.org/Current-Projects/IASB-Projects/Consolidation/Consol-disclosure/ Documents/Effect-Analysis-IFRS\%2010-and-IFRS-12-Updated-July-2013.pdf

[6] MÜLLER, V., 2011. Value Relevance of Consolidated versus Parent Company Financial Statements: Evidence from the Largest Three European Capital Markets. Accounting and Management Information Systems, 10(3), 326-350. ISSN 1583-4387.

[7] MÜller, V., I. R. CARDOS and A. I. IENCIU, 2010. Consolidation Policy: Past, Present and Future Approaches to the Concept of Control. Annals of the University of Oradea, Economic Science Series, 19(1), 541-547. ISSN 1582-5450.

[8] NISKANEN, J., J. KINNUNEN and E. KASANEN, 1998. A Note on the Information Content of Parent Company versus Consolidated Earnings in Finland. European Accounting Review, 7(1), 31-40. ISSN 0963-8180.

[9] NOBES, CH., 2014. The Development of National and Transnational Regulation on the Scope of Consolidation. Accounting, Auditing \& Accountability Journal, 27(6), 9951025. ISSN 0951-3574

[10] VAN DER MERWE, C., 2013. IFRS Banking Survey: Still Far From Land? Accountancy SA, 2013(8), 24-29. ISSN 0258-7254.

[11] VAN NOORDWYK, R. and H. WISE, 2014. New Consolidation Standard: Lessons Learned So Far. Accountancy SA, 2014(5), 24-25. ISSN 0258-7254.

[12] VAŠEK, L. and T. GLUZOVÁ, 2014. Can a New Concept of Control under IFRS Have an Impact on a CCCTB? European Financial and Accounting Journal, 9(4), 110-127. ISSN 1805-4846.

[13] ZELENKOVÁ, M., 2014. Změny v pojetí ovládání a spoluovládání (Changes of Control and Joint-control Approaches). Český finanční a účetní časopis, 9(2), 18-30. ISSN 18022200 


\section{Appendix I: List of companies}

\begin{tabular}{|c|c|}
\hline No. & Name \\
\hline 1 & Alior Bank S.A. \\
\hline 2 & Asseco Poland S.A. \\
\hline 3 & Bank Handlowy w Warszawie S.A. \\
\hline 4 & Bank Pekao S.A. \\
\hline 5 & Bank Zachodni WBK S.A. \\
\hline 6 & Boryszew S.A. \\
\hline 7 & CCC S.A. \\
\hline 8 & ČEZ, a.s. \\
\hline 9 & Cyfrowy Polsat S.A. \\
\hline 10 & ENEA S.A. \\
\hline 11 & ENERGA S.A. \\
\hline 12 & Erste Group Bank AG \\
\hline 13 & EUROCASH S.A. \\
\hline 14 & Fortuna Entertainment Group N.V. \\
\hline 15 & GLOBE TRADE CENTRE S.A. \\
\hline 16 & Grupa Azoty S.A. \\
\hline 17 & Grupa LOTOS S.A. \\
\hline 18 & ING Bank Ślaski S.A. \\
\hline 19 & Jastrzębska Spólka Węglowa S.A. \\
\hline 20 & KGHM Polska Miedź S.A. \\
\hline 21 & Komerční banka, a.s. \\
\hline 22 & LLP S.A. \\
\hline 23 & Lubelski Węgiel Bogdanka S.A. \\
\hline 24 & mBank S.A. \\
\hline 25 & New World Resources Plc \\
\hline 26 & O2 Czech Republic, a.s. \\
\hline 27 & Orange Polska S.A. \\
\hline 28 & Pegas Nonwovens SA \\
\hline 29 & PGE Polska Grupa Energetyczna S.A. \\
\hline 31 & Phillip Morris ČR, a.s. \\
\hline 30 & PKN ORLEN S.A. \\
\hline 32 & PKO Bank Polski S.A. \\
\hline 33 & Polskie Górnictwo Naftowe i Gazownictwo S.A. \\
\hline 34 & Powszechny Zakład Ubezpieczeń S.A. \\
\hline 35 & STOCK SPIRITS GROUP PLC \\
\hline 36 & Synthos S.A. \\
\hline 37 & Tauron Polska Energia S.A. \\
\hline 38 & TVN S.A. \\
\hline 39 & UNIPETROL, a.s. \\
\hline 40 & VIENNA INSURANCE GROUP \\
\hline
\end{tabular}

Source: author 